\title{
Human Gastrointestinal Juices Intended for Use in In Vitro Digestion Models
}

\author{
Ellen K. Ulleberg • Irene Comi • Halvor Holm • \\ Espen B. Herud • Morten Jacobsen • Gerd E. Vegarud
}

Received: 28 June 2011 / Accepted: 28 September 2011 /Published online: 15 October 2011

(C) The Author(s) 2011. This article is published with open access at Springerlink.com

\begin{abstract}
The aim of this study was to characterise the individual human gastric and duodenal juices to be used in in vitro model digestion and to examine the storage stability of the enzymes. Gastroduodenal juices were aspirated, and individual variations in enzymatic activities as well as total volumes, $\mathrm{pH}$, bile acids, protein and bilirubin concentrations were recorded. Individual pepsin activity in the gastric juice varied by a factor of 10 , while individual total proteolytic activity in the duodenal juice varied by a factor of 5. The duodenal amylase activity varied from 0 to $52.6 \mathrm{U} / \mathrm{ml}$, and the bile acid concentration varied from 0.9 to $4.5 \mathrm{mM}$. Pooled gastric and duodenal juices from 18 volunteers were characterised according to pepsin activity $(26.7 \mathrm{U} / \mathrm{ml})$, total proteolytic activity $(14.8 \mathrm{U} / \mathrm{ml})$, lipase activity $(951.0 \mathrm{U} / \mathrm{ml})$, amylase activity $(26.8 \mathrm{U} / \mathrm{ml})$ and bile acids $(4.5 \mathrm{mM})$. Stability of the main enzymes in two frozen batches of either gastric or duodenal juice was studied for 6 months. Pepsin activity decreased rapidly and adjusting the $\mathrm{pH}$ of gastric juice to 4 did not protect the pepsin from degradation. Lipase activity remained stable
\end{abstract}

E. K. Ulleberg $(\bowtie) \cdot$ I. Comi $\cdot$ M. Jacobsen $\cdot$ G. E. Vegarud Department of Chemistry, Biotechnology \& Food Science, Norwegian University of Life Sciences,

1432 Ås, Norway

e-mail: ellen.ulleberg@umb.no

H. Holm

Department of Nutrition, Institute for Basic Medical Sciences, University of Oslo,

0316 Oslo, Norway

E. B. Herud · M. Jacobsen

Oestfold Hospital Trust,

Fredrikstad, Norway for 4 months, however decreased rapidly thereafter even after the addition of protease inhibitors. Glycerol only marginally stabilised the survival of the enzymatic activities. These results of compositional variations in the individual gastrointestinal juices and the effect of storage conditions on enzyme activities are useful for the design of in vitro models enabling human digestive juices to simulate physiological digestion.

Keywords Gastric juice · Duodenal juice · Enzymes · Individual variation $\cdot$ Storage stability

\section{Introduction}

Several approaches to mimic in vivo digestion have been suggested over the years. Some of the purposes have been to investigate whether food components could produce bioactive components $[1,2]$, to study the survival of drugs through the gastrointestinal (GI) tract [3, 4] or to predict the digestibility of food proteins including allergens [5-9].

A recent review on in vitro human digestion models by Hur et al. [10] demonstrates the vast variability of digestive fluids used and emphasises the importance of using physiologically relevant levels of enzymes and other minor components when designing these fluids. Most previously reported in vitro digestion models have been performed with commercial digestive enzymes of porcine or bovine origin [2, 11-14]. To increase lipolysis, bile salts of various concentrations have been added [10], and also proteolysis has been shown to increase upon the addition of bile salts [15]. It was recently demonstrated that whey proteins digested by human gastroduodenal 
juices produced different peptides compared to digestion with porcine digestive enzymes [16]. Human digestive juices contain enzymes of various isoforms that may differ from purified animal enzymes with regard to both specificity and activity [17-19]. Enzyme activities have been estimated by different methods in different studies; thus, the outcomes will vary and will rely on the assay conditions such as the $\mathrm{pH}$, temperature, substrate, incubation time and the detection method used [10]. Consequently, a direct comparison between studies is challenging. Human digestive juices contain enzymes and cofactors in a physiological combination and may therefore represent an advantage over artificial solutions composed of purified commercial enzymes. However, all physiological mechanisms operative in vivo are not transplantable to any in vitro setting.

In order to reduce the inter-individual variations and to be able to perform several comparable in vitro gastrointestinal digestion assays, batches of pooled gastric and intestinal juices are required. The specific activities of the enzymes in such pooled samples must be analysed, and their stability during storage should be monitored so that the juices are used while the enzymes are still active. Loss of pepsin activity in frozen gastric juice has been reported [20]. However, de Gara et al. [20] showed that the activity could be preserved by the addition of glycerol or by increasing the $\mathrm{pH}$ outside of the optimal $\mathrm{pH}$ range for pepsin. The amylase activity in duodenal juice stored at $-20{ }^{\circ} \mathrm{C}$ remained largely stable in a study by Muller and Ghale [21] whereas lipase and trypsin activities in hormonally stimulated juice decreased to approximately $50 \%$ of the initial activities within 3 weeks. Furthermore, it has been suggested that adding protease inhibitors would result in a protective effect on the lipase activity as chymotrypsin has been shown to digest the lipase [22]. Based on this knowledge, we designed the present study with the following aims:

1. To establish a practical and convenient method for the collection of human intestinal juices from the upper digestive tract from a number of volunteers

2. To describe the individual variations in enzymatic activities as well as total volumes, $\mathrm{pH}$, bile acids, total protein and bilirubin concentrations, of gastric and duodenal juices

3. To study the stability of enzyme activities in gastric and duodenal juices using different storage temperatures $\left(-20{ }^{\circ} \mathrm{C},-80{ }^{\circ} \mathrm{C}\right.$ or liquid nitrogen $), \mathrm{pH}$ adjustment or the addition of glycerol or protease inhibitors

4. To characterise the pooled samples of gastric and duodenal juices enabling several in vitro digestion experiments to be carried out under similar conditions

\section{Methods}

Collection of Physiological Gastric and Duodenal Juices from the Upper Digestive Tract

Human gastric (HGJ) and duodenal (HDJ) juices were collected according to Holm et al. [23] from healthy volunteers without previous history of health impairments. Aspirations of in total 20 fasting volunteers $(7$ men and 13 women) aged between 20 to 42 years (average $25 \pm 5$ years) were performed at Moss Hospital. The volunteers were allowed to drink water ad libitum prior to the placement of the tube. The aspiration was approved by the Norwegian Ethics Committee, and all volunteers had given a written consent to participate in the study. GI juices were collected by placing a flexible three-lumen silicone tube (Fig. 1a) developed by Maxter Catheters (Marseilles, France) especially for this type of study through the nose or mouth of the volunteer. Correct placement of the tube was monitored by radiology (Fig. 1b). Continuous instillation, $100 \mathrm{ml} / \mathrm{h}$ of an isotonic stimulatory solution $(17.5 \mathrm{~g} / 1$ sucrose, $450 \mathrm{mg} /$ $1 \mathrm{NaCl}, 800 \mathrm{mg} / \mathrm{l} \mathrm{L}$-phenylalanine and $575 \mathrm{mg} / \mathrm{l} \mathrm{L}$-valine in $\mathrm{H}_{2} \mathrm{O}$ ) [24] and a continuous aspiration of gastric and duodenal fluids were performed simultaneously. The stimulation solution was instilled close to the papilla of Vater, while the duodenal juice was aspirated some $10 \mathrm{~cm}$ distally. Juices from the stomach were aspirated from the canalis ventriculi. The GI juices were collected in $50 \mathrm{ml}$ tubes on ice, inspected and $\mathrm{pH}$ was measured periodically to avoid samples of mixed duodenal and gastric juices. Digestive juice collected from the stomach was discarded if the juice was yellow in colour and had a $\mathrm{pH}>4$. These samples were found to have low pepsin activity and high total proteolytic activity. Similarly, digestive juice of clear colour and $\mathrm{pH} \leq 4$ collected from the duodenum was also discarded. These samples had low total proteolytic activity and high pepsin activity as a result of gastric juice leakage to the duodenum (results not shown). The experiment lasted approximately $2 \mathrm{~h}$ per individual. The samples were centrifuged $(4,500 \times g$ for $10 \mathrm{~min}$ ) to remove mucous, and cell debris before aliquots were frozen at $-20^{\circ} \mathrm{C}$ and then stored at $-20{ }^{\circ} \mathrm{C}$ or $-80{ }^{\circ} \mathrm{C}$.

\section{Outline of the Study}

The study was designed in three parts

Part I: Recording of individual variations in enzymatic activities, bile acids, total protein and bilirubin concentrations as well as $\mathrm{pH}$ and total volumes of gastric and duodenal juices. Due to technical disorganisation of all the individual aspirates, some enzyme activities and component analysis are missing in the data set. 

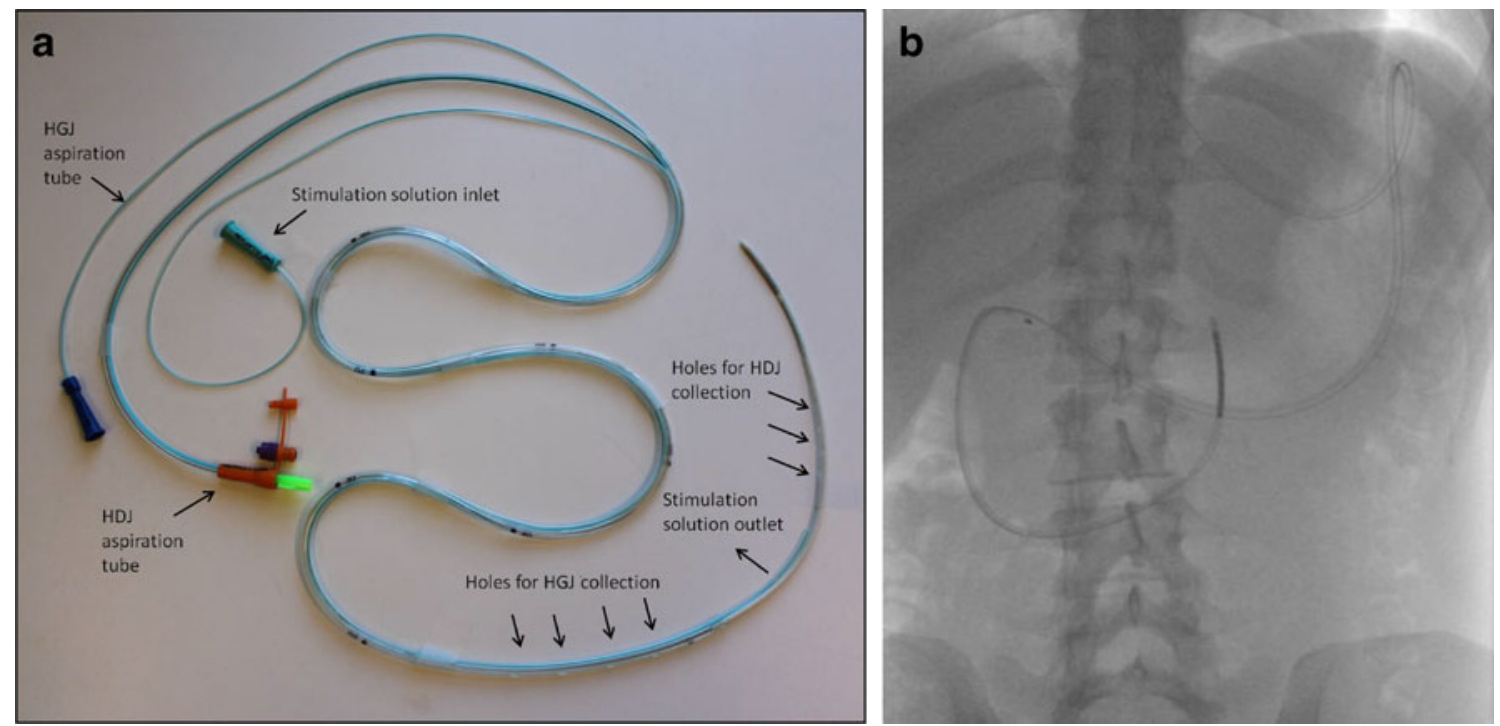

Fig. 1 a Detailed description of the three-lumen tube used for the aspiration of gastric and duodenal juices. $H G J$ gastric juice, $H D J$ duodenal juice (photo: Ellen K. Ulleberg). b Correct placement of the

Part II: Recording of storage stability. In order to examine the effect of different storage conditions on the stability of proteolytic, lipase and amylase activities, we pooled samples of gastric and duodenal juices, respectively, from two individuals ( 25 years old, one female and one male). The pooled gastric juice was divided into three subsamples: one control sample (no additions), one sample with glycerol added to a final concentration of $13 \%$ and one sample adjusted to $\mathrm{pH} 4$ using a $0.2-\mathrm{M}$ citrate buffer. The pooled duodenal juice was divided into seven subsamples: one control sample (no additions), one sample stored in liquid nitrogen $\left(\mathrm{N}_{2}\right.$, no additions), one sample with glycerol added to a final concentration of $13 \%$ and four samples with protease inhibitors added: (a) $29 \mathrm{mg} / \mathrm{ml}$ Pefabloc (Pentapharm Ltd, Basel, Switzerland), (b) $4 \mathrm{mg} / \mathrm{ml}$ Camostat mesilate (1879 China Langchem Inc., China), (c) $4 \mathrm{mg} / \mathrm{ml}$ Bowman Birk inhibitor (BBI; T9777, SigmaAldrich, St. Louis, MO, USA) or (d) a mixture of $4.5 \mathrm{mg} / \mathrm{ml} \mathrm{BBI}$ and $34 \mathrm{mg} / \mathrm{ml}$ Pefabloc. All juices were aliquoted and stored at $-80{ }^{\circ} \mathrm{C}$ unless otherwise is stated. The enzymatic activities were analysed on the day of collection and every month for 6 months.

Part III: Recording of changes in enzyme activities in pooled samples of HGJ and HDJ during longterm storage. For practical reasons, collection of a large number of samples may require a long period of time. Consequently, samples will have to be stored/frozen for different times before being pooled. To study this situation, samples of gastric three-lumen aspiration tube in the stomach and duodenum of a volunteer as monitored by radiology (photo: Espen B. Herud)

and duodenal juices from 18 individuals (6 males and 12 females, average age $24 \pm 5$ years) were pooled. The individual juices were collected and stored at $-80{ }^{\circ} \mathrm{C}$ from 7 to 15 months prior to pooling them. The pooled juices were aliquoted and stored at $-20^{\circ} \mathrm{C}$ or at $-80^{\circ} \mathrm{C}$. Registration of $\mathrm{pH}$, volume and enzymatic activities as well as total bile acid, protein and bilirubin concentrations were performed on the day of making the pooled samples. Storage stability of the enzymatic activities in the frozen juices was then observed over a 12-month period after pooling the samples.

\section{Proteolytic Activities of Gastric and Duodenal Enzymes}

HGJ was analysed for pepsin activity at $\mathrm{pH} 3.0$ with haemoglobin (H2625, Sigma, St. Louis, MO, USA) as substrate according to Sanchez-Chiang et al. [25]. Pepsin activity was assayed within 2 months after aspiration. HDJ was analysed for total proteolytic activity at $\mathrm{pH} 8.0$ with casein (Hammarstein casein, Merck Co., Darmstadt, Germany) as substrate, as described by Krogdahl and Holm [26] and Kirschenbaum [27]. In brief, triplicates of human gastric or duodenal juices in three concentrations were incubated with substrate for $10 \mathrm{~min}$ at $37^{\circ} \mathrm{C}$, and the reactions were stopped by the addition of trichloroacetic acid. After an overnight sedimentation at $4{ }^{\circ} \mathrm{C}$, the samples were centrifuged for $10 \mathrm{~min}$ at $3,000 \times \mathrm{g}$. One unit of enzyme activity was defined as the amount (in millilitres) of gastric or duodenal juice giving a difference in absorbance of 1.0 at $280 \mathrm{~nm}$ in $10 \mathrm{~min}$ at $37^{\circ} \mathrm{C}$. 


\section{Lipase Activity}

Pancreatic lipase activity in the HDJ was measured in triplicates using the LIP, lipase colorimetric assay for serum analysis in automated systems, Roche Diagnostics $\mathrm{GmbH}$ (Mannheim, Germany). This assay is performed at $\mathrm{pH} 8$ and uses the non-diglyceride chromogenic lipase substrate 1,2-O-dilauryl-rac-glycero-3-glutaric acid-(6-methylresorufin) ester. In brief, the samples were mixed with colipase in $\mathrm{N}, \mathrm{N}$-bis(2-hydroxyethyl)-glycine buffer, in a 96 -well plate on ice and incubated at $37^{\circ} \mathrm{C}$ for 5 min. After adding the substrate, the colour reaction was measured photometrically every $10 \mathrm{~s}$ for $5 \mathrm{~min}$ at $595 \mathrm{~nm}$. The lipase cleaves the substrate to produce 1,2-O-dilauryl-racglycerol and the unstable glutaric acid-(6-methylresorufin) ester which then decomposes spontaneously producing the chromophore methylresorufin. The HDJ samples were diluted in $0.9 \% \mathrm{NaCl}(1: 10-1: 100)$ depending on the activity of the juices. One unit of lipase activity was defined as the amount (in millilitres) of HDJ giving a difference in velocity ( $\triangle \mathrm{OD}$, rate of methylresorufin production) of 1.0 at $595 \mathrm{~nm} /$ $\min$ at $37^{\circ} \mathrm{C}$.

\section{Amylase Activity}

HDJ was analysed for pancreatic amylase activity at Oestfold Hospital Trust using the ADVIA 1650 chemistry systems (Siemens Medical Solutions, Erlangen, Germany). The amylase in the sample splits the ethylidene- $p$-nitrophenyl-maltoheptaoside substrate, and together with added glucosidase, this leads to the release of free $p$-nitrophenol which is measured due to its absorbance at 410/694 $\mathrm{nm}$. Two dilutions (1:5 and 1:10 in $0.9 \% \mathrm{NaCl}$ ) of the HDJ were made, and the average of the two were used to calculate the amylase activity. One unit of amylase is defined as that amount of HDJ, which catalyses the production of $1 \mu \mathrm{mol}$ of $p$-nitrophenol per minute under the conditions of the method.

\section{Bile Acids}

Bile acid concentration was analysed in duplicates after dilution with distilled water (1:50) at the Central Laboratory of the Norwegian School of Veterinary Science (Oslo, Norway) using Advia ${ }^{\circledR} 1650$ (Bayer Healthcare, Tarrytown, NY, USA), an automated analysis system for clinical chemistry. Principles of analyses were based on enzymatic amplification determining total $3 \alpha$-hydroxy bile acids using a kit (Bio-stat Diagnostic systems, Stockport, UK). In the presence of Thio-NAD, the enzyme $3 \alpha$-hydroxysteroid dehydrogenase converts bile acids to 3-keto steroids and Thio-NADH. The rate of formation of Thio-NADH was measured spectrophotometrically at $410 \mathrm{~nm}$. The bile acid concentration was determined using a curve generated from a standardised taurocholic acid solution.

\section{Total Protein Concentration}

The total protein concentrations in the gastric and duodenal juices were measured in triplicates using the Qubit $^{\mathrm{TM}}$ Fluorometer (Invitrogen) with the Quant-IT ${ }^{\mathrm{TM}}$ protein assay kit (Invitrogen) according to the manufacturer's instructions.

\section{Bilirubin Concentration}

Bilirubin concentration in the duodenal juices was analysed at Oestfold Hospital Trust using the ADVIA 1650 chemistry systems (Siemens Medical Solutions, Erlangen, Germany). Vanadate is used to oxidize bilirubin and thereby creating biliverdin. The optical density of the yellow colour of bilirubin $(451 / 545 \mathrm{~nm})$ is thereby decreased proportionally to the total bilirubin concentration in the duodenal juices. Two dilutions (1:5 and 1:10 in $0.9 \%$ $\mathrm{NaCl}$ ) of the HDJ were made, and the average of the two were used to calculate the concentration of bilirubin.

\section{Statistical Analysis}

Normality of the individual data (volumes, total protein, enzyme activities, bile acids and bilirubin) was tested using the Shapiro-Wilk and the Kolmogorov-Smirnov tests using the SAS software, version 9.2 (SAS Institute Inc., Cary, NC, USA).

\section{Results}

Total volumes and $\mathrm{pH}$ of the gastric and duodenal juices collected from 18 volunteers over a 2 -h period are presented in Table 1 . The $\mathrm{pH}$ of the gastric juice varied from 1 to 4 . The total volume of the individual gastric juices varied with a minimum of $2 \mathrm{ml}$ and a maximum output of $355 \mathrm{ml}$, with an average of $87 \pm 103 \mathrm{ml}$. The total volume of duodenal juice for each individual ranged from 10 to $312 \mathrm{ml}$ with an average of $158 \pm 91 \mathrm{ml}$ and a $\mathrm{pH}$ between 5 and 9. A normal distribution of the data for HGJ volumes was only obtained after logarithmic transformation of the numbers, whereas the original data for HDJ volumes were normally distributed (data not shown). It was observed that for ten of the volunteers, substantial volumes of gastric juice $(20$ to $123 \mathrm{ml}$ ) seemed to leak and mix with the duodenal juice. Three of the volunteers also experienced reflux of duodenal juice (10 to $30 \mathrm{ml}$ ) to the gastric compartment (Table 1). These samples were discarded from further analysis. 
Table 1 Total volumes and periodically measured $\mathrm{pH}$ during the collection of the gastric and duodenal juices from 18 individuals
$F$ female, $n d$ not determined, $M$ male, $S D$ standard deviation

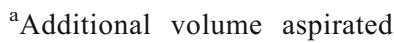
from the duodenal tube with $\mathrm{pH} \leq 4$

${ }^{\mathrm{b}}$ Additional volume aspirated from the gastric tube with $\mathrm{pH}>4$

\begin{tabular}{|c|c|c|c|c|c|c|c|c|}
\hline \multicolumn{3}{|l|}{ Volunteer } & \multicolumn{3}{|c|}{ Gastric juice } & \multicolumn{3}{|c|}{ Duodenal juice } \\
\hline No & Age & Gender & $\mathrm{pH}$ & Volume (ml) & $-{ }^{\mathrm{a}}$ & $\mathrm{pH}$ & Volume (ml) & $-^{\mathrm{b}}$ \\
\hline 1 & 24 & $\mathrm{~F}$ & nd & 65 & & nd & 161 & \\
\hline 2 & 21 & $\mathrm{~F}$ & 4 & 13 & & 7 & 27 & \\
\hline 3 & 22 & $\mathrm{~F}$ & 2 & 17 & 30 & $6-7$ & 100 & \\
\hline 4 & 42 & $\mathrm{~F}$ & 1 & 355 & 50 & $5-9$ & 205 & \\
\hline 5 & 20 & M & $1-2$ & 222 & 115 & $7-8$ & 110 & \\
\hline 6 & 20 & $\mathrm{~F}$ & 2 & 55 & 37 & $6-8$ & 155 & \\
\hline 7 & 24 & $\mathrm{~F}$ & $3-4$ & 110 & & $6-7$ & 30 & 14 \\
\hline 8 & 21 & $\mathrm{~F}$ & 4 & 25 & & 6 & 10 & 10 \\
\hline 9 & 20 & M & 2 & 15 & 35 & $5-7$ & 218 & \\
\hline 10 & 30 & $\mathrm{~F}$ & $1-4$ & 198 & & $6-7$ & 30 & \\
\hline 11 & 34 & M & $3-4$ & 13 & & $5-7$ & 152 & \\
\hline 12 & 21 & $\mathrm{~F}$ & 1 & 28 & 123 & $7-8$ & 197 & \\
\hline 13 & 26 & M & $3-4$ & 37 & & $5-7$ & 168 & 30 \\
\hline 14 & 24 & $\mathrm{~F}$ & 4 & 10 & 99 & $5-7$ & 285 & \\
\hline 15 & 22 & M & 4 & 31 & & $5-7$ & 253 & \\
\hline 16 & 24 & $\mathrm{~F}$ & $2-3$ & 121 & 20 & $6-7$ & 244 & \\
\hline 17 & 24 & $\mathrm{~F}$ & 1 & 2 & 73 & $6-7$ & 312 & \\
\hline 18 & 23 & M & 1 & 248 & 73 & $6-8$ & 185 & \\
\hline Average & 25 & & & 87 & & & 158 & \\
\hline SD & 6 & & & 103 & & & 91 & \\
\hline
\end{tabular}

The individual differences in enzymatic activities and the concentrations of bile acids, total protein and bilirubin are described in Table 2. Data for the enzymatic activities, bile acids and total protein showed normal distribution, whereas bilirubin was only normally distributed if the very high concentration found for volunteer 17 was removed (data not shown). The pepsin activities of the gastric juices ranged from 7 to $70 \mathrm{U} / \mathrm{ml}$, with an average activity of $37 \pm 21 \mathrm{U} / \mathrm{ml}$. A high volume of HGJ did not result in a decreased pepsin activity or vice versa $(r=-0.55)$. The total proteolytic activity of the individual duodenal juice did not vary to the same extent ranging from approximately 5 to $25 \mathrm{U} / \mathrm{ml}$, with an average of $16 \pm 6 \mathrm{U} / \mathrm{ml}$. The correlation between volume and total proteolytic activity was $r=0.14$. The duodenal amylase activity ranged from 0 to $50 \mathrm{U} / \mathrm{ml}$ with an average of $27 \pm 15 \mathrm{U} / \mathrm{ml}$. A high variation in total bile acid and bilirubin concentrations was also observed with average values of $2.7( \pm 1.3) \mathrm{mM}$ and $59( \pm 59) \mu \mathrm{M}$, respectively. Total protein concentrations in gastric and duodenal juice were $1.1( \pm 0.3)$ and $1.4( \pm 0.7) \mathrm{mg} / \mathrm{ml}$, respectively. Correlations between gastric and duodenal output volumes and pepsin versus total proteolytic activity outputs were $r=-0.10$ and $r=0.20$, respectively.

Gastric and duodenal juices from two volunteers were pooled on the day of aspiration, and the stability of the enzymatic activities was monitored for 6 months. The stability of the pepsin activity in the gastric juice and the amylase, total proteolytic and lipase activities in the duodenal juice is illustrated in Fig. 2. Two months after aspiration, approximately $80 \%$ of the pepsin activity remained. Then, after 3 months, the activity seemed to stabilise at approximately $60 \%$ of the initial pepsin activity. The addition of glycerol or a $\mathrm{pH}$ adjustment of the gastric juice did not protect the pepsin from degradation (data not shown). The amylase activity in the pooled duodenal juice did not decrease during storage, and a decay of only approximately $10 \%$ total proteolytic activity was observed. No decrease in lipase activity in the pooled duodenal juice was measured during the first 4 months in samples stored at $-80{ }^{\circ} \mathrm{C}$. After 6 months, however, approximately $75 \%$ of the initial activity remained. None of the added protease inhibitors seemed to protect the lipase from degradation. On the contrary, the addition of Pefabloc to the duodenal juice resulted in a rapid decrease in the lipase activity (data not shown).

We have previously performed in vitro digestion assays using HGJ and HDJ aspirated from only one individual [16, 28-30]. During five aspiration periods, this individual produced HGJ with pepsin activities ranging from 12 to $95 \mathrm{U} / \mathrm{ml}$ (average $59 \pm 34 \mathrm{U} / \mathrm{ml}$ ) and $\mathrm{HDJ}$ with total proteolytic activities ranging from 19 to $27 \mathrm{U} / \mathrm{ml}$ (average $23 \pm 4 \mathrm{U} / \mathrm{ml}$ ). Due to the intra- and intersubject variability observed and in order to have enough juice to perform several comparable in vitro digestion studies, aspirated 
Table 2 Individual differences in the composition of human gastric and duodenal juice

\begin{tabular}{|c|c|c|c|c|c|c|c|}
\hline Volunteer & $\begin{array}{l}\text { Total protein in HGJ } \\
(\mathrm{mg} / \mathrm{ml})\end{array}$ & $\begin{array}{l}\text { Pepsin } \\
(\mathrm{U} / \mathrm{ml})\end{array}$ & $\begin{array}{l}\text { Total protein in HDJ } \\
(\mathrm{mg} / \mathrm{ml})\end{array}$ & $\begin{array}{l}\text { Total proteolytic } \\
(\mathrm{U} / \mathrm{ml})\end{array}$ & $\begin{array}{l}\text { Amylase } \\
(\mathrm{U} / \mathrm{ml})\end{array}$ & $\begin{array}{l}\text { Bile acids } \\
(\mathrm{mM})\end{array}$ & $\begin{array}{l}\text { Bilirubin } \\
(\mu \mathrm{M})\end{array}$ \\
\hline 1 & nd & nd & nd & 21.0 & nd & nd & nd \\
\hline 2 & nd & 70.5 & nd & 16.0 & nd & nd & nd \\
\hline 3 & nd & 20.6 & nd & 16.4 & nd & nd & nd \\
\hline 4 & nd & 7.4 & nd & 14.4 & nd & nd & nd \\
\hline 5 & nd & nd & nd & 19.6 & nd & nd & nd \\
\hline 6 & nd & 7.3 & nd & 16.6 & nd & nd & nd \\
\hline 7 & 1.0 & 32.4 & 2.0 & 13.0 & 24.9 & 3.2 & 47.5 \\
\hline 8 & 1.0 & 55.9 & 1.0 & 12.0 & 49.8 & 0.9 & 22.5 \\
\hline 9 & 1.3 & 59.5 & 2.4 & 19.8 & 35.5 & 3.6 & 57.1 \\
\hline 10 & 0.8 & nd & 1.3 & 11.7 & 0.0 & 1.3 & 5.5 \\
\hline 11 & 1.3 & nd & 2.6 & 25.4 & 33.0 & 3.4 & 47.3 \\
\hline 12 & 0.9 & nd & 1.4 & 11.5 & 22.0 & 3.3 & 69.0 \\
\hline 13 & 1.4 & nd & 1.1 & 23.9 & 52.6 & 4.2 & 85.2 \\
\hline 14 & 1.5 & nd & 0.5 & 10.4 & 29.2 & 2.2 & 39.8 \\
\hline 15 & 0.9 & nd & 1.4 & 5.6 & 10.0 & 3.3 & 58.0 \\
\hline 16 & 1.1 & 42.2 & 2.2 & 24.7 & 25.8 & 4.5 & 32.8 \\
\hline 17 & 1.7 & 45.2 & 0.6 & 22.8 & 28.6 & 1.6 & 232.6 \\
\hline 18 & 0.5 & 32.0 & 1.0 & 9.4 & 13.0 & 1.0 & 17.9 \\
\hline Average & 1.1 & 37.3 & 1.4 & 16.3 & 27.0 & 2.7 & 59.6 \\
\hline SD & 0.3 & 21.5 & 0.7 & 5.8 & 15.2 & 1.3 & 58.9 \\
\hline
\end{tabular}

Pepsin activity $(n=10)$ and total protein concentration $(n=12)$ in individual human gastric juices. Total proteolytic activity $(n=18)$, amylase activity, bile acid, protein and bilirubin concentrations $(n=12)$ in individual human duodenal juices

$H G J$ human gastric juice, $H D J$ human duodenal juice, $n d$ not determined, $S D$ standard deviation

gastric and duodenal juices collected from 18 individuals were pooled. A total of 1,300 $\mathrm{ml} \mathrm{HGJ}$ and 2,100 $\mathrm{ml}$ HDJ were collected. Table 3 shows the characteristics of the pooled gastric juice (18p HGJ) and the pooled duodenal juice (18p HDJ) with respect to $\mathrm{pH}$, volume, enzyme activities, bile acid, total protein and bilirubin concentrations. The pooled gastric juice had a $\mathrm{pH}$ of 1.7 , a total protein concentration of $1.2 \mathrm{mg} / \mathrm{ml}$ and a pepsin activity of $26.7 \mathrm{U} / \mathrm{ml}$. The pooled duodenal juice had a $\mathrm{pH}$ of 7.0, a total proteolytic activity of $14.8 \mathrm{U} / \mathrm{ml}$, a lipase activity of $951.0 \mathrm{U} / \mathrm{ml}$ and an amylase activity of $26.8 \mathrm{U} / \mathrm{ml}$. The duodenal juice bile acid concentration was $4.5 \mathrm{mM}$, and the total protein and bilirubin concentrations were $2.0 \mathrm{mg} / \mathrm{ml}$ and $67.5 \mu \mathrm{M}$, respectively.

The stability of the enzymatic activities in the pooled gastric and duodenal juices $(n=18)$ were further studied for a 12-month storage period at $-20{ }^{\circ} \mathrm{C}$ and $-80{ }^{\circ} \mathrm{C}$ (Fig. 3). The individual juices had been stored for 7 to 15 months prior to pooling the samples. During the first 3 months after pooling, the pepsin activity decreased rapidly to about $65 \%$ of the original activity at both storage temperatures. The activity, however, remained more stable thereafter if stored at $-80{ }^{\circ} \mathrm{C}$ ending at $55 \%$ of the original activity whereas storage at $-20{ }^{\circ} \mathrm{C}$ resulted in only $36 \%$ of the original activity remaining after 12 months. In the pooled duodenal juice, the total proteolytic activity seemed more stable and decreased by only approximately $15 \%$ after 12 months storage at both $-20{ }^{\circ} \mathrm{C}$ and $-80{ }^{\circ} \mathrm{C}$. The lipase activity, however, decreased rapidly and only about $40 \%$ of the activity remained 5 months after pooling the duodenal juice. After 12 months storage at both $-20^{\circ} \mathrm{C}$ and $-80{ }^{\circ} \mathrm{C}$, approximately $40 \%$ of the initial lipase activity still remained. The amylase activity remained largely stable throughout the 12-month storage period.

\section{Discussion}

Several models simulating in vivo digestion have been developed using commercial enzymes. Obviously, no model can internalize all potential variability in enzyme secretion created by hormonal, peptide and neural regulation in each individual. The amount and composition of intestinal fluids vary between individuals and according to the type and amount of food ingested [4, 31, 32]. Any sampling is therefore only representative of the sampling moment, reflecting the state in which the volunteer was in at that time. In the fasting state, secretion of intestinal fluid 
Fig. 2 Percentage remaining pepsin activity in a pooled sample of human gastric juice and remaining amylase, lipase and total proteolytic activities in a pooled sample of human duodenal juice stored at $-80{ }^{\circ} \mathrm{C}$ for 6 months

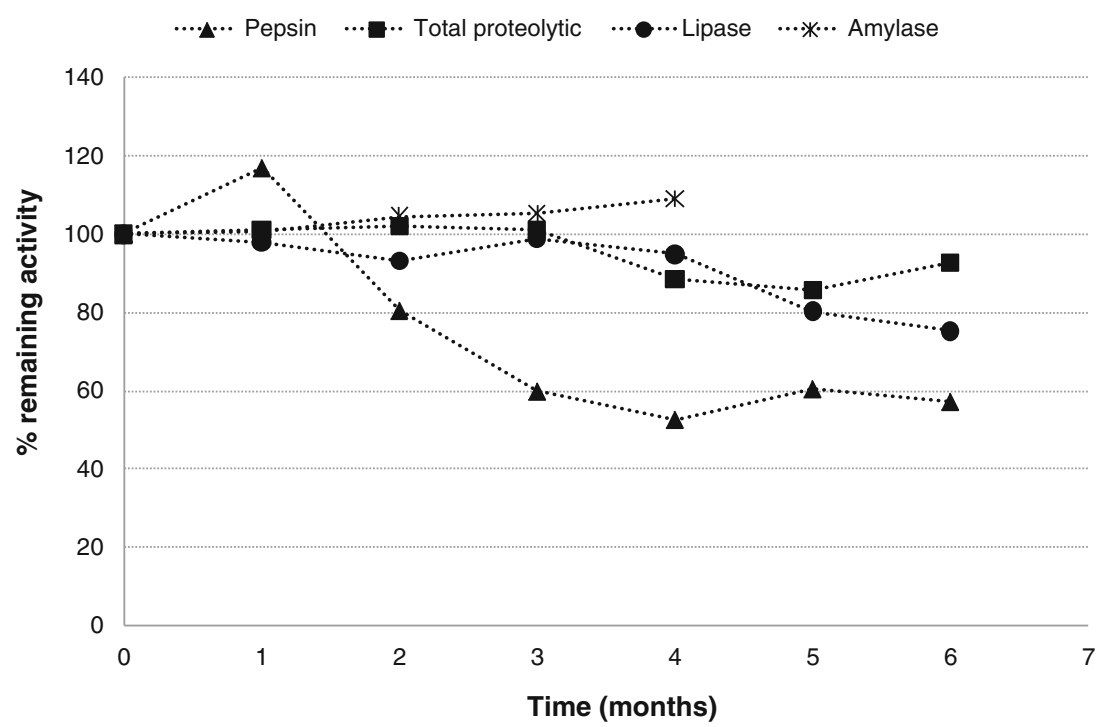

is scarce [33], and collection of larger amounts requires an extended collection period. In our study, the volunteers had fasted for a minimum period of $12 \mathrm{~h}$ prior to collection of GI juices, so in order to stimulate pancreatic secretion, a stimulation solution was used. Test meals containing protein, carbohydrates and lipids would have enhanced the secretion but would at the same time have "contaminated" the gastric and duodenal juices intended for in vitro digestion of food components. To circumvent this problem, we used a combination of amino acids and salt known to stimulate pancreatic enzyme and bile secretion [24] during the aspiration. The volunteers were therefore neither in a fasting nor in a fed state at the time of aspiration.

The variation in composition of human gastric and duodenal juices in both fasting and fed stages has previously been characterised [31, 32]. Our study showed that the individual variations in $\mathrm{pH}$, aspiration volumes, enzymatic activities and bile acids are substantial. The volunteers displayed a gastric $\mathrm{pH}$ ranging from 1 to 4 which is in accordance with the fasting $\mathrm{pH}$ of healthy young individuals reported by others to be in the range of 1.0-3.5 $[34,35]$. However, this may also vary especially according to age as young children tend to have elevated gastric $\mathrm{pH}$ and lower amount of pepsin compared to adults [33].
Ingestion of food also temporarily raises the $\mathrm{pH}$ in the stomach and leads to increased secretion of pepsin $[32,36]$. Our pooled HDJ had a pH of 7 while Dressman et al. [35] showed that the duodenal juice of fasting healthy young individuals had a median $\mathrm{pH}$ of 6.1. However, intersubject variations could be substantial [32].

The large variations in the volumes of gastric and duodenal juice observed were partly due to dilution by the stimulatory solution as shown by Holm et al. [23]. Under similar conditions, the average dilution of infusates was 1:1.64 and gastric reflux was less than 5\% [23]. In addition, the emotional states of the volunteers during the aspiration could also change the secretions [37]. We observed that the more relaxed volunteers would generally produce more juice and that individuals being very uncomfortable in the situation were more likely to produce less. Furthermore, the mere thought of food seemed to increase the juice output. However, no correlation between the production volumes of gastric and duodenal juices was observed. Approximately 24-ml gastric juice is, according to Lydon et al. [38], present in the fasting stomach. We measured an average total volume of $87 \mathrm{ml}$ after $2 \mathrm{~h}$ aspiration which is in agreement with the reported flow rate of $0.9 \mathrm{ml} / \mathrm{min}$ [33]; however, considerable intersubject variation (2 to $355 \mathrm{ml}$ ) was observed. Daily

Table 3 Characterisation of the pooled gastric juice sample (18p HGJ) and the pooled duodenal juice sample (18p HDJ) from 18 volunteers

\begin{tabular}{lllllllll}
\hline & $\mathrm{pH}$ & $\begin{array}{l}\text { Volume } \\
(\mathrm{ml})\end{array}$ & $\begin{array}{l}\text { Total protein } \\
(\mathrm{mg} / \mathrm{ml})\end{array}$ & $\begin{array}{l}\text { Pepsin } \\
\text { activity }(\mathrm{U} / \mathrm{ml})\end{array}$ & $\begin{array}{l}\text { Total proteolytic } \\
\text { activity }(\mathrm{U} / \mathrm{ml})\end{array}$ & $\begin{array}{l}\text { Lipase } \\
\text { activity }(\mathrm{U} / \mathrm{ml})\end{array}$ & $\begin{array}{l}\text { Amylase } \\
\text { activity }(\mathrm{U} / \mathrm{ml})\end{array}$ & $\begin{array}{l}\text { Bile acids } \\
(\mathrm{mM})\end{array}$ \\
\hline 18p HGJ & 1.7 & 1,300 & 1.2 & 26.7 & - & - & - & - \\
$(\mu \mathrm{M})$ & & - & - \\
$18 \mathrm{p}$ HDJ & 7.0 & 2,100 & 2.0 & - & 14.8 & 951.0 & 26.8 & 4.5 \\
\hline
\end{tabular}

$18 p H G J$ pooled human gastric juice from 18 individuals, $18 p H D J$ pooled human duodenal juice from 18 individuals 
Fig. 3 Long-term storage stability of pepsin in a frozen sample of pooled human gastric juice and stability of total proteolytic, amylase and lipase activities in a frozen sample of pooled human duodenal juices stored at $-20{ }^{\circ} \mathrm{C}$ or $-80{ }^{\circ} \mathrm{C}$. The individual juices had been collected and stored at $-80{ }^{\circ} \mathrm{C}$ from 7 to 15 months prior to pooling them and were then observed for 12 months

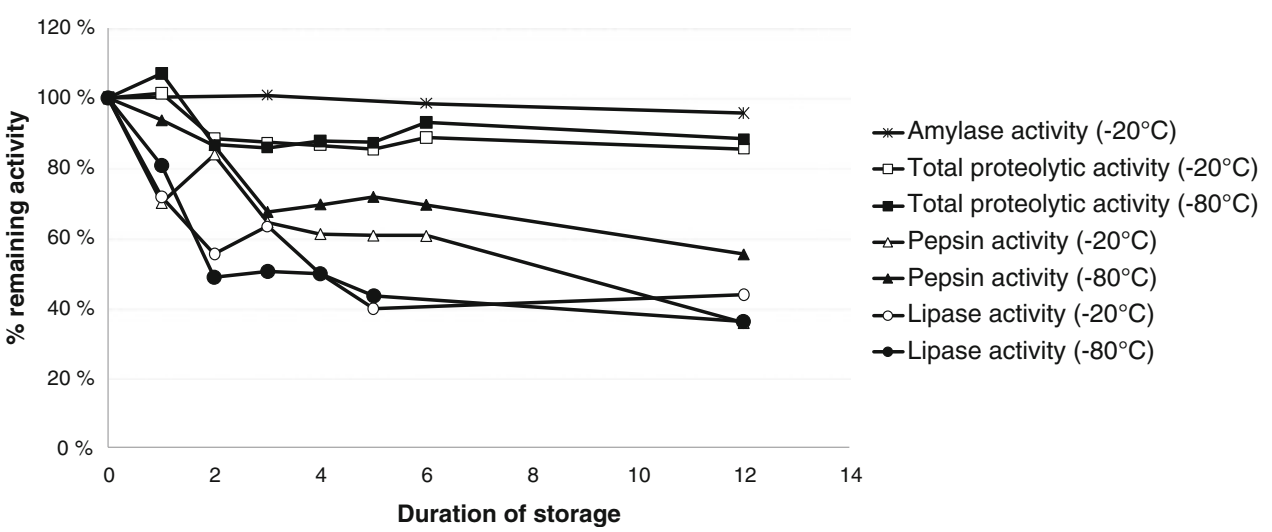

outputs of duodenal juice have previously been reported to be in the range of 700-2,500 $\mathrm{ml}$ [39] which is in accordance with the $158-\mathrm{ml}$ average volume within the 2 -h collection period in this study. The duodenal juice volumes were highly variable ranging from 10 to $312 \mathrm{ml}$. This is in accordance with Moreno et al. [40] who reported that duodenal juice volumes collected over a 2-h period ranged from 40 to $355 \mathrm{ml}$

In order to standardise the composition of the juices with the purpose of performing in vitro model digestion of food, we pooled the GI juice samples from all volunteers. The $\mathrm{pH}$ in the gastric juice was 1.7 , and the $\mathrm{pH}$ of the duodenal juice was 7.0 which correlated well with the aforementioned normal $\mathrm{pH}$ values observed by others [32, 34, 35, 40]. Basal pepsin output has previously been reported to be approximately $0.87 \mathrm{mg} / \mathrm{ml}$ pepsin [33, 41]. The pooled gastric juice $(n=18)$ had a pepsin activity of $27 \mathrm{U} / \mathrm{ml}$ with an individual variation of 7 to $70 \mathrm{U} / \mathrm{ml}$. According to Holm et al. [42], average basal total proteolytic activity in duodenal juice is approximately $45 \mathrm{U} / \mathrm{ml}$ (ranging from 11 to $135 \mathrm{U} / \mathrm{ml}$ ). Our pooled duodenal juice, however, displayed a total proteolytic activity of $15 \mathrm{U} / \mathrm{ml}$ with less intersubject variation ( 5 to $25 \mathrm{U} / \mathrm{ml}$ ). The total bile acid concentration in the pooled duodenal juice $(n=18)$ was $4.5 \mathrm{mM}$ with an individual variation from 0.9 to $4.5 \mathrm{mM}$ in 12 of the 18 subjects. This is in agreement with the values reported by Moreno et al. [40] and Clarysse et al. [31] showing fasting state bile acid concentration in duodenal juice ranging from 0.6 to 5.1 and $0.3-9.6 \mathrm{mM}$, respectively. Lindahl et al. [43] measured a mean protein concentration of 1.8 ranging from 0.7 to $3.9 \mathrm{mg} / \mathrm{ml}$ in the fasting gastric juice of 24 individuals. This agrees with the present study measuring a total protein concentration in the pooled gastric juice to be $1.2 \mathrm{mg} / \mathrm{ml}$ (from 0.5 to $1.7 \mathrm{mg} / \mathrm{ml}$ ). The total protein concentration in the pooled duodenal juice was measured to be $2.0 \mathrm{mg} / \mathrm{ml}$, which is somewhat lower than the $3.1-\mathrm{mg} / \mathrm{ml}$ median value observed by Kalantzi et al. [32]. We measured an amylase activity of $27 \mathrm{U} / \mathrm{ml}$ and a lipase activity of $951 \mathrm{U} / \mathrm{ml}$ in the pooled duodenal juice. Others have used different assays to measure these enzymatic activities in duodenal juice, and a comparison of the values obtained is therefore hampered.

Enzymatic activities in digestive juices have been known to deteriorate during storage [20-22, 44]. In order to use pooled gastroduodenal juices in in vitro digestion studies, the stability of the individual enzyme activities needs to be monitored and preferably stabilised to avoid substantial decrease in activities. Glycerol has by many been used as a cryoprotector to avoid loss of enzyme activities in stored gastric and duodenal juice [20, 44, 45]. The addition of $13 \%$ glycerol to freshly isolated gastric and duodenal juices only marginally protected the enzymes from degradation compared to the control in this study. This is contrary to the results by Sivakumaran et al. [44] demonstrating no loss in pepsin activity when adding glycerol in the range of 20 to $280 \mathrm{ml} / \mathrm{l}$. In our study, the pepsin activity in the pooled gastric juice $(n=18)$ was reduced to approximately $40-55 \%$ remaining activity after 12 months frozen storage. Some of this loss may be due to the ambient $\mathrm{pH} 1.7$ in the pooled juice as the critical lowest $\mathrm{pH}$ of 1.8 has been demonstrated to avoid loss in pepsin activity [20]. We were, however, not able to preserve the pepsin activity by increasing the gastric juice $\mathrm{pH}$ to 4 . Gastric juice should therefore not be stored for more than 1-2 months before being used for protein digestion to avoid loss in pepsin activity.

In the frozen pooled duodenal juice stored for 12 months, only the amylase activity remained stable. This is in agreement with the study by Muller and Ghale [21]. We observed that about $80-90 \%$ of the original total proteolytic activity remained in the pooled duodenal juice. Kelly et al. [22] showed that whereas the chymotrypsin activity remained rather stable in duodenal juice stored for 56 days, the trypsin activity displayed intersubject variability ranging from $0 \%$ to $25 \%$ decrease in activity. In the study by Muller and Ghale [21], the trypsin activity decreased to less than $60 \%$ in a third of the samples. This could indicate that a loss in trypsin activity could account for some of the loss in the total proteolytic activity observed in this study. The lipase activity appeared to remain stable up to 4 months after aspiration but then decreased steadily during storage. A 
significant loss in lipase activity upon frozen storage was also observed by Kelly et al. [22] who concluded that the loss in lipase activity was caused by chymotryptic digestion as the lipase activity remained stable if the duodenal juice was incubated with a chymotrypsin inhibitor. This is also in agreement with Thiruvengadam and DiMagno [46] who confirmed this and also reported that tryptic activity had little or no effect on lipase degradation. After adding several protease inhibitors (all inhibitors of both chymotrypsin and trypsin) to freshly aspirated duodenal juice, we did, however, not observe any protection of the lipase activity during frozen storage. The addition of casein, acting as an alternative substrate for the chymotrypsin, could also have been used to protect the lipase from degradation [22]. However, as we intend to use the duodenal juice for in vitro digestion of milk proteins, the addition of any protease inhibitor or foreign protein would be out of the question.

Several models simulating in vivo digestion have been established $[8,47]$ including both simple static models and more sophisticated dynamic models such as the TNO gastrointestinal tract model (TIM) [48] and the dynamic gastric model and small intestinal simulation developed at the Institute of Food Research (Norwich, UK) [8]. All of these models have so far used simulated gastrointestinal fluids with commercial enzymes of animal origin and commercial bile salts. The use of human GI juices may present several advantages. The complex composition of these physiological digestive fluids better reflects the in vivo ratio of the different enzymes and isoenzymes as well as other minor components. Previous results demonstrating that human gastric and duodenal juices produce different digestion products compared to porcine purified digestion enzymes strongly support this view [16]. The inter- and intrasubject variability should always be taken into consideration. A range of concentrations of HGJ and HDJ could possibly be used to reflect the individual variability in the amounts of enzymes and bile salts as observed in this study and by others [43]. A simulation of fasted and fed situations could also be obtained by varying the amount of juices added.

\section{Conclusions}

Characterisation of individual gastrointestinal juices gives a valuable overview of the large variation in the composition, $\mathrm{pH}$ and volumes that can be valid during digestion and is an important tool when designing simulated digestion of foods. In order to enable the comparison of results from several digestion studies, large pooled samples of individual digestive juices have to be used. Since both pepsin and lipase activities were reduced during frozen storage, even when preservatives were added, fresh juices or juices frozen for only a short period (1-2 months) is to be preferred.

Acknowledgements This work was supported by the Norwegian University of Life Sciences and Oestfold Hospital Trust. We wish to thank Maxter Catheters for providing the custom-made aspiration tubes used in this study. In addition, the great assistance offered by the staff at Oestfold Hospital Trust was greatly appreciated. Thanks also for the excellent statistical guidance offered by Thomas Ulleberg.

Conflict of Interest The authors report no conflict of interest and are alone responsible for the content and writing of this manuscript.

Open Access This article is distributed under the terms of the Creative Commons Attribution Noncommercial License which permits any noncommercial use, distribution, and reproduction in any medium, provided the original author(s) and source are credited.

\section{References}

1. Korhonen H, Pihlanto A (2006) Bioactive peptides: production and functionality. Int Dairy J 16:945-960

2. Escudero E, Sentandreu MA, Toldra F (2010) Characterization of peptides released by in vitro digestion of pork meat. J Agric Food Chem 58:5160-5165

3. Jantratid E, Janssen N, Reppas C, Dressman JB (2008) Dissolution media simulating conditions in the proximal human gastrointestinal tract: an update. Pharm Res 25:1663-1676

4. Dressman JB, Amidon GL, Reppas C, Shah VP (1998) Dissolution testing as a prognostic tool for oral drug absorption: immediate release dosage forms. Pharm Res 15:11-22

5. Moreno FJ, Mellon FA, Wickham MS, Bottrill AR, Mills EN (2005) Stability of the major allergen Brazil nut $2 \mathrm{~S}$ albumin (Ber e 1) to physiologically relevant in vitro gastrointestinal digestion. FEBS J 272:341-352

6. Astwood JD, Leach JN, Fuchs RL (1996) Stability of food allergens to digestion in vitro. Nat Biotechnol 14:1269-1273

7. Fu TJ, Abbott UR, Hatzos C (2002) Digestibility of food allergens and nonallergenic proteins in simulated gastric fluid and simulated intestinal fluid - a comparative study. J Agric Food Chem 50:7154-7160

8. Wickham M, Faulks R, Mills C (2009) In vitro digestion methods for assessing the effect of food structure on allergen breakdown. Mol Nutr Food Res 53:952-958

9. Savoie L, Gauthier SF (1986) Dialysis cell for the in vitro measurement of protein digestibility. J Food Sci 51:494-498

10. Hur SJ, Lim BO, Decker EA, McClements DJ (2011) In vitro human digestion models for food applications. Food Chem 125:112

11. Hernández-Ledesma B, Quirós A, Amigo L, Recio I (2007) Identification of bioactive peptides after digestion of human milk and infant formula with pepsin and pancreatin. Int Dairy J 17:4249

12. Bordenave S, Sannier F, Ricart G, Piot J-M (2000) Characterization of a goat whey peptic hydrolysate produced by an ultrafiltration membrane enzymic reactor. J Dairy Res 67:551559

13. Schmelzer CEH, Schöps R, Reynell L, Ulbrich-Hofmann R, Neubert RHH, Raith K (2007) Peptic digestion of beta-casein. 
Time course and fate of possible bioactive peptides. J Chromatogr A 1166:108-115

14. Kim SB, Ki KS, Khan MA, Lee WS, Lee HJ, Ahn BS, Kim HS (2007) Peptic and tryptic hydrolysis of native and heated whey protein to reduce its antigenicity. J Dairy Sci 90:4043-4050

15. Gass J, Vora H, Hofmann AF, Gray GM, Khosla C (2007) Enhancement of dietary protein digestion by conjugated bile acids. Gastroenterology 133:16-23

16. Eriksen EK, Holm H, Jensen E, Aaboe R, Devold TG, Jacobsen M, Vegarud GE (2010) Different digestion of caprine whey proteins by human and porcine gastrointestinal enzymes. $\mathrm{Br} \mathrm{J}$ Nutr 104:374-381

17. Whitcomb DC, Lowe ME (2007) Human pancreatic digestive enzymes. Dig Dis Sci 52:1-17

18. Chiang L, Sanchez-Chiang L, Mills JN, Tang J (1967) Purification and properties of porcine gastricsin. J Biol Chem 242:3098-3102

19. Roberts NB (2006) Review article: human pepsins - their multiplicity, function and role in reflux disease. Aliment Pharmacol Ther 24(Suppl 2):2-9

20. de Gara CJ, Burget DW, Sivakumaran T, Hunt RH (1986) The effect of temperature and $\mathrm{pH}$ on the stability of human pepsin in stored gastric juice. A method to prevent activity loss. Scand J Gastroenterol 21:650-654

21. Muller DP, Ghale GK (1982) Stability of pancreatic enzyme activities in duodenal juice after pancreatic stimulation by a test meal or exogenous hormones. Ann Clin Biochem 19:89-93

22. Kelly DG, Sternby B, DiMagno EP (1991) How to protect human pancreatic enzyme activities in frozen duodenal juice. Gastroenterology 100:189-195

23. Holm H, Hanssen LE, Krogdahl A, Florholmen J (1988) High and low inhibitor soybean meals affect human duodenal proteinase activity differently: in vivo comparison with bovine serum albumin. J Nutr 118:515-520

24. Go VLW, Hofmann AF, Summerskill WHJ (1970) Pancreozymin bioassay in man based on pancreatic enzyme secretion: potency of specific amino acids and other digestive products. J Clin Invest 49:1558-1564

25. Sanchez-Chiang L, Cisternas E, Ponce O (1987) Partial purification of pepsins from adult and juvenile salmon fish Oncorhynchus keta. Effect of $\mathrm{NaCl}$ on proteolytic activities. Comp Biochem Physiol B 87:793-797

26. Krogdahl A, Holm H (1979) Inhibition of human and rat pancreatic proteinases by crude and purified soybean proteinase inhibitors. J Nutr 109:551-558

27. Kirschenbaum DM (1975) Molar absorptivity and A1 cm $1 \%$ values for proteins at selected wavelengths of the ultraviolet and visible regions. XI. Anal Biochem 68:465-484

28. Eriksen EK, Vegarud GE, Langsrud T, Almaas H, Lea T (2008) Effect of milk proteins and their hydrolysates on in vitro immune responses. Small Ruminant Research 79:29-37

29. Almaas H, Cases A-L, Devold TG, Holm H, Langsrud T, Aabakken L, Aadnoey T, Vegarud GE (2006) In vitro digestion of bovine and caprine milk by human gastric and duodenal enzymes. Int Dairy J 16:961-968

30. Almaas H, Holm H, Langsrud T, Flengsrud R, Vegarud GE (2006) In vitro studies of the digestion of caprine whey proteins by human gastric and duodenal juice and the effects on selected microorganisms. Br J Nutr 96:562-569

31. Clarysse S, Tack J, Lammert F, Duchateau G, Reppas C, Augustijns P (2009) Postprandial evolution in composition and characteristics of human duodenal fluids in different nutritional states. J Pharm Sci 98:1177-1192

32. Kalantzi L, Goumas K, Kalioras V, Abrahamsson B, Dressman JB, Reppas C (2006) Characterization of the human upper gastrointestinal contents under conditions simulating bioavailability/bioequivalence studies. Pharm Res 23:165-176

33. Lentner C (1981) Geigy scientific tables. Units of measurement, body fluids, composition of the body, nutrition. CIBA-GEIGY, Basel

34. Fallingborg J (1999) Intraluminal pH of the human gastrointestinal tract. Dan Med Bull 46:183-196

35. Dressman JB, Berardi RR, Dermentzoglou LC, Russell TL, Schmaltz SP, Barnett JL, Jarvenpaa KM (1990) Upper gastrointestinal (GI) $\mathrm{pH}$ in young, healthy men and women. Pharm Res 7:756-761

36. Chatterton DEW, Rasmussen JT, Heegaard CW, Sørensen ES, Petersen TE (2004) In vitro digestion of novel milk protein ingredients for use in infant formulas: research on biological functions. Trends Food Sci Technol 15:373-383

37. Mittelmann B, Wolff HG (1942) Emotions and gastroduodenal function: experimental studies on patients with gastritis, duodenitis and peptic ulcer. Psychosom Med 4:5-61

38. Lydon A, Murray C, McGinley J, Plant R, Duggan F, Shorten $\mathrm{G}$ (1999) Cisapride does not alter gastric volume or $\mathrm{pH}$ in patients undergoing ambulatory surgery. Can J Anaesth 46:1181-1184

39. Elmslie RG, White TT, Magee DF (1964) Observation on pancreatic function in eight patients with controlled pancreatic fistulas: including a review of the literature. Ann Surg 160:937949

40. Moreno MPdlC, Oth M, Deferme S, Lammert F, Tack J, Dressman J, Augustijns P (2006) Characterization of fasted-state human intestinal fluids collected from duodenum and jejunum. $\mathrm{J}$ Pharm Pharmacol 58:1079-1089

41. Schmidt HA, Fritzlar G, Dolle W, Goebell H (1970) Comparative studies on the histamine and insulin stimulated acid pepsin secretion in patients suffering from ulcus duodeni and control persons. Dtsch Med Wochenschr 95:2011-2016

42. Holm H, Krogdahl A, Hanssen LE (1988) High and low inhibitor soybean meals affect human duodenal proteinase activity differently: in vitro comparison of proteinase inhibition. J Nutr 118:521-525

43. Lindahl A, Ungell A-L, Knutson L, Lennernas H (1997) Characterization of fluids from the stomach and proximal jejunum in men and women. Pharm Res 14:497-502

44. Sivakumaran T, de Gara CJ, Walker WH, Silletti C, Burget D, Hunt RH (1984) Stability of gastric-juice pepsin, and a method for its preservation. Clin Chem 30:1582-1583

45. Hajduk E, Fik M (1990) Application of glycerol to freezing bovine pancreas. 1. Effect of cryoprotector on activity of certain enzymes in frozen minced pancreas. Nahrung-Food 34:75-79

46. Thiruvengadam R, DiMagno EP (1988) Inactivation of human lipase by proteases. Am J Physiol 255:G476-G481

47. Kong F, Singh RP (2008) Disintegration of solid foods in human stomach. J Food Sci 73:R67-R80

48. Minekus M, Marteau P, Havenaar R, Huisintveld JHJ (1995) A multicompartmental dynamic computer-controlled model simulating the stomach and small-intestine. Atla-Alternatives to Laboratory Animals 23:197-209 